\title{
ИСПОЛЬЗОВАНИЕ ВИДЕОКОНФЕРЕНЦ-СВЯЗИ ПРИ РАССЛЕДОВАНИИ УГОЛОВНЫХ ДЕЛ
}

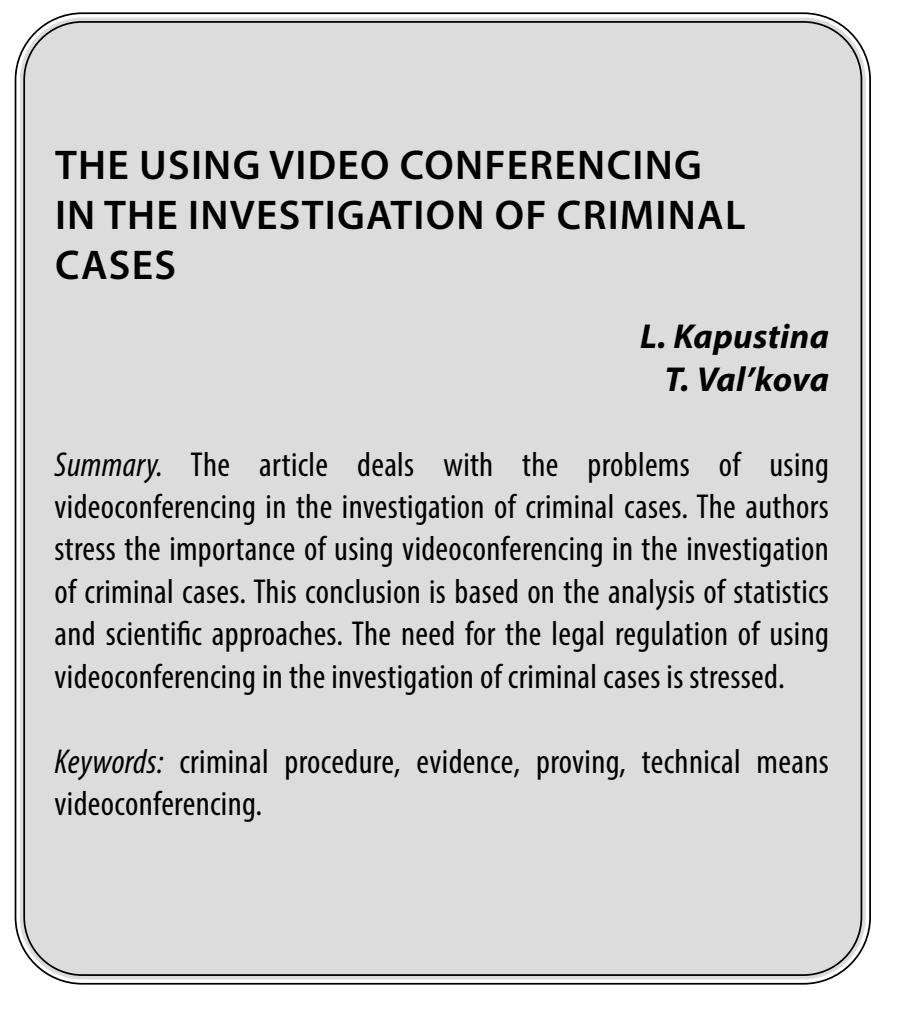

Summary. The article deals with the problems of using videoconferencing in the investigation of criminal cases. The authors stress the importance of using videoconferencing in the investigation of criminal cases. This conclusion is based on the analysis of statistic and scientific approaches. The need for the legal regulation of using videoconferencing in the investigation of criminal cases is stressed.

Keywords: criminal procedure, evidence, proving, technical means videoconferencing.

развитием информационных технологий возникают новые требования к формам коммуникации. Стоит отметить, что в условиях недавно произошедших событий, затронувших все мировое сообщество [2], широкое распространение получили технологии беспроводной передачи информации.

В условиях принятия мер по противодействию распространению коронавирусной инфекции, а также соблюдения разумных сроков предварительного расследования, назрела необходимость в использовании средств видеоконференц-связи (далее ВКС) на стадии предварительного расследования.

На сегодняшний день законодатель закрепил порядок использования ВКС лишь для судебной стадии. Так ст. 240 и ст. 278.1 УПК РФ предусматривают возможность использования судом систем ВКС в целях допроса свидетеля [9]. При организации допроса свидетеля путем использования систем ВКС, учитываются следующие моменты:

1. суд, находящийся по месту жительства свидетеля, организует проведение допроса с использованием систем BKC;
Капустина Лилия Константиновна

Преподаватель, Санкт-Петербургский университет МВД России liliakapustina90@gmail.com

Валькова Татьяна Владимировна

К.ю.н., дочент, Санкт-Петербургский университет МВД России

Аннотация. В статье рассматриваются проблемы использования видеоконференц-связи при расследовании уголовных дел. В статье на основании анализа действующего уголовно-процессуального законодательства и правоприменительной практики делается вывод о значимости применения видеоконференц-связи на стадии предварительного расследования. Авторы приходят к выводу о том, что использование видеоконференц-связи при расследовании уголовных дел требует правовой регламентации и технического оснащения отделов полиции.

Ключевые слова: уголовное судопроизводство, доказывание, доказательства, технические средства, видеоконференц-связь.

2. суд по месту жительства удостоверяет личность свидетеля, а также истребует подписку о разъяснении прав, обязанностей и ответственности, предусмотренных ст. 56 УПК РФ, которая направляется в суд, рассматривающий уголовное дело.

3. допрос проводится в соответствии со ст. 278 УПК PФ.

Несмотря на то, что использование систем ВКС регламентировано лишь для судебной стадии, действующее уголовно-процессуально законодательство не запрещает, а косвенно указывает на такую возможность, о чем свидетельствует ч. 6 ст. 164 УПК РФ, предусматривающая применение технических средств. Возможность использования систем ВКС в рамках расследования преступлений подтверждается результатами анализа научных трудов и правоприменительной практики.

Сегодня в науке все чаще внимание уделяется не столько обоснованию необходимости использования ВКС на досудебных стадиях, сколько изучению процессуально верного алгоритма ее применения [1, с. $46-53 ; 5$, с. 38-39; 7, с. 291-300; 10, с. 117], посколь- 
ку перечень причин ее востребованности достаточно велик.

Проведенный анализ научной литературы [6, с. 99; 8, 188-122] и правоприменительной практики позволил обозначить следующие преимущества, которые могла бы предоставить система ВКС в случае ее применения на стадии предварительного расследования:

1. обеспечение безопасности допрашиваемого лица;

2. обеспечение разумного срока предварительного расследования;

3. сокращение материальных затрат, связанных с обеспечением прибытия допрашиваемого лица в место производства предварительного расследования;

4. преодоление препятствий, связанных с нахождением лица в местах лишения свободы или содержанием под стражей;

5. повышение качества предварительного расследования за счет того, что следственные действия осуществляются лицом, в производстве которого находится уголовное дело;

6. проведение предварительного расследования в условиях соблюдения мер по противодействию распространению коронавирусной инфекции.

Несмотря на обширный перечень преимуществ применение системы ВКС на стадии предварительного расследования до настоящего времени не имеет правовой регламентации. Справедливости ради отметим, на сегодняшний день подготовлен законопроект № 1184595-7, которым предлагается внести ряд изменений в УПК РФ, предоставив следователю право допроса посредством ВКС [3]. В отличие от законопроекта № 434998-7 от 5 апреля 2018 года [4], в законопроекте № 1184595-7 расширен круг лиц, которых возможно допросить с помощью ВКС, а именно наряду со свидетелем появляется возможность допроса потерпевшего, специалиста и эксперта.

В тексте законопроекта № 1184595-7, находящегося на рассмотрении в Государственной Думе РФ [3], содержатся сведения о возможных условиях, порядке и основании отказа в проведении допроса посредством ВКС. К условиям использования ВКС при допросе авто- ры законодательной инициативы относят: невозможность личного участия лица в допросе; нахождение за пределами места производства предварительного расследования; основания, при которых допрос должен проводиться исключительно лицом, в производстве которого находится уголовное дело.

К основаниям, запрещающим использование ВКС при допросе, относятся: возможность разглашения государственной тайны; возможность разглашения данных о лице, в отношении которого приняты меры безопасности.

В тексте законопроекта содержится следующий порядок осуществления допроса с использованием ВКС:

1. следователь или дознаватель, в производстве которого находится уголовное дело, направляет поручение об организации допроса;

2. орган предварительного следствия или дознания, находящийся по месту жительства допрашиваемого лица: организует проведение допроса с использованием систем ВКС, удостоверяет личность допрашиваемого, составляет протокол и после проведения допроса направляет его инициатору поручения;

3. инициатор допроса после получения протокола посредством ВКС подписывает его;

4. допрос производится в соответствии со ст. 189 и ст. 191 УПК РФ.

Изложенное, позволяет сделать вывод о том, что появившаяся тенденция, обуславливающая необходимость правовой регламентации использования систем ВКС в ходе предварительного расследования, не может не радовать. Такой способ получения доказательственной информации, как производство допроса с использованием видеоконференц-связи, сократит материальные затраты и сроки расследования, позволит увеличить оперативность и повысить качество получения необходимой информации. В связи с этим вопросы правовой регламентации использования видеоконференц-связи при расследовании уголовных дел и соответствующего технического оснащения отделов полиции требуют скорейшего разрешения.

\section{ЛИТЕРАТУРА}

1. Авдонин К.В., Черкасов В.С. Видеоконференц-связь в следственных действиях: как правильно использовать и что поменять в УПК / К.В. Авдонин, В.С. Черкасов // Уголовный процесс.—2018. — № 7.- С. 46-53.

2. Вступительное слово Генерального директора В03 на пресс брифинге по COVID-19-11 августа 2021 г. [Электронный ресурс] // Режим доступа: https:// www.who.int/ru/director-general/speeches/detail/who-director-general-s-opening-remarks-at-the-media-briefing-on-covid-19-11-august-2021.

3. Законопроект № 1184595-7 «0 внесении изменений в Уголовно-процессуальный кодекс Российской Федерации» [Электронный ресурс] // Режим доступа: https://sozd.duma.gov.ru/bill/1184595-7\#bh_note. 
4. Законопроект № 434998-7 «0 внесении изменений в Уголовно-процессуальный кодекс Российской Федерации» [Электронный ресурс] // Режим доступа: http://asozd2c.duma.gov.ru/addwork/scans.nsf/ID/BAE69922D1COB01B43258266005F6F81/\$FILE/434998-7_05042018_434998-7.PDF? 0penElement.

5. Лебедев Н.Ю. Отсутствие законодательного закрепления процедуры допроса с использованием систем видеоконференц-связи в ходе предварительного расследования - одна из причин возникновения конфликтных ситуаций / Н.Ю. Лебедев / Сборник материалов криминалистических чтений. - 2015.- - С. 38-39.

6. Мазунин Я.М. Организационные особенности производства допроса с использованием видеоконференц-связи / Я.М. Мазунин, К.С. Сидорова / Технологии XXI века в юриспруденции: материалы Всероссийской научно-практической конференции, г. Екатеринбург, 24-25 мая 2019 г.—- Екатеринбург, 2019. - C. 98-102.

7. Новиков С.А. Допрос в ходе досудебного производства: направления совершенствования / С.А. Новиков / Обвинение и защита по уголовным делам: исторический опыт и современность: сборник статей по материалам Международной научно-практической конференции, посвященной 100-летию со дня рождения профессора Н.С. Алексеева, г. Санкт-Петербург, 28-29 июня 2014 г. — Санкт-Петербург, 2014. — С. $291-300$.

8. Родивилина В.А. Потенциальная возможность использования систем видеоконференц-связи на предварительном расследовании / В.А. Родивилина, А.А. Шаевич / Проблемы современного законодательства России и зарубежных стран: материалы VI Международной научно-практической конференции, г. Иркутск, 08 декабря 2017 г.: В 2 Т. — Иркутск, 2017. - С. 118-122.

9. Уголовно-процессуальный кодекс Российской Федерации: федеральный закон от 18 декабря 2001 года № 177-Ф3 (ред. 0т 01.07.2021) // Собрание законодательства РФ. — 2001. — № 52 (ч.І), ст. 4921.

10. Щерба С.П., Архипова Е.А. Правовые основы применения видеоконференц-связи в уголовном судопроизводстве России и перспективы их совершенствования / С.П. Щерба, Е.А. Архипова // Уголовное право.—2014. — № 4.— С. 109-117.



